Antelope has been since named Hunter's Antelope (Damalis hunteri) by Mr. Sclater (see Proc. Zool. Soc., 1879 , p. 372 , Pl. xlii.), and mounted specimens of it may be seen in the Mammal Gallery of the Natural History Museum at South Kensington.

It must not, however, be supposed that the rich mammal-fauna of the Kilimanjarô district has been yet entirely exhausted. We read, in Sir John Willoughby's narrative, of a Duiker Antelope (Cephalophus), of a dark red colour, found on the mountain, of which a specimen was obtained by an American traveller, Dr. Abbott, but not by the British sportsmen. On the same mountain, at an elevation of about 9000 feet, Dr. Abbott also secured an example of an "extraordinary animal" like a Serow (i.e. Capricornis bubalina of the Himalayas), but "darker in colour and shorter on the legs." There is therefore ample room for future discoveries, both in this and in other branches of natural history. The plateau surrounding Mount Kenia, which has yet to be explored scientifically, would doubtless supply many other novelties. In short, at the present time we know of no other field for zoological discovery so promising and so easily accessible as the slice of Eastern Africa recently assigned to Sir William Mackinnon and his associates of the B.I.E.A. Company, to which the author of the present volume has given us such a useful and agreeable introduction.

\section{THE CORAL REEFS OF THE JAVA SEA AND ITS VICINITY.'}

SINCE comparatively few of the naturalists who have sojourned in the Indian Archipelago have paid special attention to the coral reefs of that region, it becomes a cause of satisfaction that Dr. C. Ph. Sluiter, of Batavia, who has long been engaged in studying the marine fauna of his neighbourhood, has taken up the subject in earnest. In a paper on the origin of the coral reefs of the Java Sea, and of Brandewijns Bay on the west coast of Sumatra, and on the new coral formations of Krakatão, Dr. Sluiter gives the results of his recent preliminary investigations. ${ }^{2}$ This paper is excellent in method, and the results of the highest importance.

In the western half of Batavia Bay, where the depth varies from 5-12 fathoms, there are numerous coral reefs which occur in all stages of growth from the incipient reef to the coral island begirt with a barrierreef. Being curious to learn how the corals first began to grow on the muddy bottom of this bay, the author of this paper soon found an explanation in the fact that the stones and fragments of sunken Krakatao pumice, which lay in places on the mud, were covered with living corals. Hence he concluded that in those favourable circumstances where several of the stones and pumice fragments lay close together we might have the beginning of a reef. A singular feature in the growth of these reefs then attracted his attention. Some fourteen years ago, an artesian boring was made in the small coral island of Onrust in Batavia Bay, when an accumulation, 20 metres thick, of coral débris, shells, and clay, was found to pass downward into a firmer clay. The depth of the sea around is only II metres, and after allowing about 2 metres for the height of the island, Dr. Sluiter infers that the coral fragments have sunk down 7 metres into the mud or clay of the sea-bottom.

To support this view, the author gives a section of the shore-reef of Brandewijns Bay, on the west coast of Sumatra, the section being constructed from data supplied by fifteen borings, none deeper than 24 metres, the

1 "Einiges über die Entstehung der Korallenriffe in der Javasee und Branntweinsbai. und über neue Korallenbildung bei Krakatau." Von Dr. C. Ph. Sluiter. (Batavia en Noordwijk: Ernit and Co., r889.)

${ }_{2}$ Natuurkundig Tijdschrift voor Nederixndsch Indiu', Band xlix. reef there being rather under 300 metres wide. As is there shown, the volcanic formations of the steep coastborder descend at a precipitous angle under the sea, so that they do not form a foundation for the shore-reef. This reef, the thickness of which varies greatly, being in some places as much as I I metres and in others only half that amount, lies on "a substratum of clay or mud mixed with coral débris, and forming a bed ranging from 2 to 7 metres in thickness." This substratum of clay and coral passes down into a clay or mud, formed from the decomposed andesitic rocks of the district, which may be firm in some places and soft in others. The next point brought out in the section is that the substratum of clay and coral débris is thickest and deepest where the underlying clay is soft, and thinnest and nearest to the surface when the clay is firm or is mixed with sand. From these and allied considerations, Dr. Sluiter passes on to the conclusion that the same process has taken place here which occurs in the construction of dams and piers on a yielding bottom, a large amount of coral materials having been sunk in the mud, whilst the reef, by its own weight, has prepared its own foundation.

Having been familiar with the appearance of Krakatao before the great eruption of 1883 , Dr. Sluiter observed some interesting changes in connection with the shorereefs of this island when he revisited it in 1888 and 1889 . The pumice and ashes at the time of the outbreak, according to the account of Dr. Verbeek, the historian of the eruption, destroyed all life in the sea around, making the sea-bottom a lifeless waste; and under an accumulation, 20 metres thick, of these materials lies the old shore-reef. In 1888 and 1889 the old condition of things was beginning to re-assert itself. In one place a young shorereef, composed mostly of madrepores, had attained a breadth of a metre, and living corals were brought up in abundance by the dredge, attached to sunken pumice. Amongst the measurements of coral growth given by the author are those relating to specimens of Madrepora nobilis, Dana, which had attained a length of from 2 to $2 \frac{1}{2}$ decimetres in a period that could not have exceeded five or six years, and was probably much less. Specimens of Porites mucronata, Dana, had also in the same period grown to a length of I decimetre.

After referring briefly to the interesting Thousand Islands, a linear group of small coral islands near Batavia, many of which, in the southern part, affect the atoll form, Dr. Sluiter sums up the results of his observations. A coral reef in the Java Sea commences its growth on a muddy bottom in the form of a colony of corals growing on the stones and sunken pumice that there lie. As it increases in extent and height, it secures its own foundation by its weight, a large amount of coral materials sinking into the mud to a depth of seven or less metres. In its upward growth it presents a level top, and displays no hollow or basin, a uniformity which it preserves until a foot from the surface, when it dies in the centre, and the agencies dwelt upon by Murray and Agassiz then co-operate in forming an atoll or a barrier-reef. Because the small coral reefs ( 500 metres wide) of the Java Sea grow up uniformly until near the surface, Dr. Sluiter places himself in partial antagonism to a portion of Murray's theory. In this, however, he has missed the point of the new view, according to which such small reefs would either have no lagoon or else possess a very shallow one. With this correction, his partial confirmation of Murray's theory becomes more complete.

We hope that, with the great facilities at his disposal, Dr. Sluiter will make an exhaustive examination of the Thousand Islands, the varied and unusual conditions of their growth rendering them particularly important as a field for thoroughly investigating the problem.

H. B. Guppy. 